\title{
Female Bioengineering: Primordial Germ Cell Differentiation of Mesenchymal Stem Cells onto Placental Scaffolds
}

\author{
Amanda Baracho Trindade Hill ${ }^{* 1,2}$, Antonio Alexandre Speri Alves ${ }^{3}$, Rodrigo da Silva Nunes Barreto ${ }^{3}$, Fabiana \\ Fernandes Bressan", Maria Angelica Miglino ${ }^{3}$ and Joaquim Mansano Garcia ${ }^{2}$
}

${ }^{1}$ Centre de recherche en reproduction et fertilité, University of Montreal, Canada

${ }^{2}$ São Paulo State University, Brazil

${ }^{3}$ School of Veterinary Medicine and Animal Sciences, University of São Paulo, SP, Brazil

${ }^{4}$ Faculty of Animal Science and Food Engineering, Department of Veterinary Medicine, University of São Paulo, Brazil

Submission: March 24, 2021; Published: April 29, 2021

*Corresponding author: Amanda Baracho Trindade Hill, Centre de recherche en reproduction et fertilité, University of Montreal, Saint-Hyacinthe, QC, Canada

Abstract

Introduction: Female infertility is a condition that is currently treated through the maximization of existing reserves; a necessity due to the fact that a true reversal of the processes leading to infertility is not yet technologically possible. This experiment examined the ability of mesenchymal stem cells to differentiate into primordial germ cells (PGC) when cultured onto the placental scaffold.

Methods: To produce the scaffolds, the cotelydons were collected and decellularized by umbilical vessel SDS perfusion. Adipose derived cells were isolated based on rapid adherence to the plastic.

Results: The isolated cells displayed the markers CD90 and CD105, while lacked CD34 and CD45. When seeded onto the scaffold, the cells successfully differentiated into PGC like cells, displaying typical PGC markers, including STELLA, OCT4, DAZL and VASA.

Discussion: These materials were chosen for their low cost and wide availability. The data in this study show the promising potential of cellscaffold complexes to support the development of female tissue engineering-based regenerative medicine therapies.

Keywords: Placenta; Female Infertility; Ovarian Regeneration; Tissue Engineering; Adipose- Derived Cells

\section{Introduction}

Assisted reproductive techniques (ART) are currently accepted as the most effective way to overcome infertility in humans [1]. In animals, however, the objective of ART is to reduce generational intervals and to propagate genetic material among breeding animal populations. The most-used ARTs are artificial insemination, embryo transfer, in vitro embryo production, and cloning. That being said, ART has some limitations, including its requirement for healthy individuals in which to apply the technology [2]. Female infertility affects $13 \%$ of women worldwide, a level of prevalence that is not limited to humans. Systematic infertility is also a pressing concern in agriculture, where it currently poses a threat to global livestock supply chains, particularly that of the dairy industry [3]. The importance of this problem in both bovine species and humans allows for a doubly beneficial translational investigation. The bovine species represent an excellent model for investigation of this topic due to the similarity of their anatomies, physiologies, and lifespans to those of humans [4]. Cows possess particularly strong similarities to humans in regard to their reproductive system, which extend to the areas of physiology, folliculogenesis, oocyte development [5], the oocyte selection processes, and age-associated endocrinal events, among among other areas [6].

Oocyte production disorders are some of the most common causes of fertility disruptions [7], and ovarian failure has been associated with autoimmune disease, toxic effects of chemotherapy, and radiotherapy, all leading to progressive ovarian depletion [8]. There are several treatment options for infertility, and the approach used depends on the root cause 
of the disorder. Options include hormonal regulation, ovarian tissue cryopreservation, autologous or allogenic transplantation, and immature or mature oocyte or embryo cryopreservation $[8,9]$. The appropriateness of autologous graft depends on the patient's condition, as the graft can cause secondary donor site injury and possesses an inherent risk of reintroduction of carcinogenic material in oncology patients $[9,10]$. Allogenic transplantation, however, is not always the preferred choice, as it runs the risk of provoking an immune response and even tissue rejection [9]. Moreover, there are several key parameters that are important for the success of the transplantation, such as graft size, transplantation site, vascularization, and oxygen levels in the transplanted area [11], that must all be taken into account when evaluating the appropriateness of a transplantation-based treatment. Additionally, the post-operative functionality of the graft depends on the condition of the transplanted follicle reserve and its activation. Once the follicles are active, the reserve of primordial follicles decreases, which, in turn, decreases the lifespan of the ovarian graft [11].

In order to overcome the risks of immune reaction by allogenic transplantation and reintroduction of undesirable material by autologous transplantation, efforts have been made to create ovarian follicles in vitro. There are several 3D models that attempt to mimic in vivo oocyte conditions in vitro, including agarose gels for in vitro oocyte maturation [12], fibronectin [13-15], fibrin [16], alginate beads [17] and alginate droplets [18]. Interestingly, when immature follicles were isolated from prepubescent mice for in vitro culture in alginate droplets and subsequent fertilization and embryo transfer, it resulted in fertile offspring [18]. The use of fibrin grafts has been shown to restore cyclicity in an infertile mouse model [16]. Although these results may encourage the use of cryopreserved oocytes in ART, some important practical challenges remain. For example, the management of an acceptable hormone treatment and oocyte collection timeframe for patients with cancer in order to avoid delays that could compromise the survival of the healthy tissue [8]. In this context, tissue engineering strategies have become clinically relevant to treat female infertility. The success of this approach depends on several factors that must be taken in consideration, including the choices of scaffold and cell source. Mainly, three types of scaffolds have been used: (1) naturally derived polymers, (2) synthetic polymer scaffolds, and (3) decellularized tissues. This third type is advantageous due to the fact that it provides a native extracellular matrix (ECM) that possesses natural biological composition, microarchitecture, and vasculature $[19,20]$.

In addition, the removal of cellular contents circumvents immune reaction by the host [20]. The ideal scaffold should have the capacity to slowly degrade, enabling remodelling by the ECM proteins secreted by the cells, which is a quality possessed by biological scaffolds [9]. Currently, the most-used decellularized tissue matrices for female reproductive regeneration are: porcine small intestinal submucosa [21-26] and amniotic membrane [27] for vaginal reconstruction, peritoneum for cervical aplasia [28], and ovary to restore ovarian function [29]. For recellularization in tissue engineering approaches, numerous cell types can be used, including tissue specific stem cells, mesenchymal stem cells, and pluripotent stem cells [10]. Regarding ovarian tissue engineering, the major problem of using tissue specific stem cells is the chance of reintroducing tumor cells $[9,10]$. It was shown that grafts obtained from bovine decellularized ovaries seeded with primary ovarian cells could initiate puberty in ovariectomized mice [29], which represents an interesting opportunity for translational medicine, although it fails to address the objective of developing an autologous system in which the oocytes would originate from the host organism. The use of pluripotent cells is clinically limited as well, especially due to their propensity for tumor formation and genetic instability [30]. Thus, mesenchymal stem cells represent a promising cell source to be used in the recellularization process, not only because they do not form tumors when injected in vivo but also because they are easy to obtain and differentiate, exert immunomodulatory effects, and are able to modulate angiogenesis, cell proliferation, and apoptosis [31,32]. as such, the aim of this study is to investigate the potential of decellularized placenta to be recellularized with adipose tissue-derived cells for further primordial germ cell differentiation.

\section{Methods}

\section{Scaffold production}

The placenta was frozen immediately after collection. The scaffolds were produced by isolation of the cotyledons and subsequential perfusion for 2 days with $0.01 \%$ sodium dodecyl sulfate (SDS) followed by 2 days of perfusion with $0.1 \%$ SDS. The decellularization process and evaluation of its accuracy were performed at Dr. Miglino's lab , after which the scaffolds were donated for the re-cellularization and differentiation experiments [33].

\section{Cell derivation and culture}

Adipose tissue samples were collected from six female Bos taurus indicus. Prior to tissue harvest, the area to be incised was washed, shaved, and anaesthetized by a local epidural injection of $2 \%$ lidocaine chlorhydrate. The tissue was then collected from the base of the tail. On average, $1 \mathrm{~g}$ of tissue was used for enzymatic digestion, which was performed with collagenase type I for $3 \mathrm{~h}$ in agitation at $37^{\circ} \mathrm{C}$. After this period, the digested tissue was washed in expansion culture medium, which is composed of Dulbecco's Modified Eagle Medium (DMEM, Invitrogen, Grand Island, USA) supplemented with $10 \%$ fetal bovine serum (FBS, Cripion, Brazil) and $2.5 \mathrm{mg} / \mathrm{mL}$ of amikacin (NovaFarma, Brazil). After centrifugation, the pellet was transferred into a T25 culture flask (Corning, New York, USA), and the medium was changed three hours after the beginning of the culture, a protocol that has been previously described for the selection of a mesenchymal stem cell population at the first passage $[34,35]$. 


\section{Cell differentiation}

To verify the mesenchymal nature of the isolated cells, a differentiation test was performed in three biological and technical replicates. During the 21 days of the differentiation procedure, the medium was changed every 4 days, and commercial differentiation medium kits were used for osteogenic and chondrogenic differentiation (StemPro; Thermo Fisher Scientific). In order to evaluate lineage differentiation, cytochemical staining was performed following the manufacturer's instructions. Von Kossa stain was used for osteogenic differentation and Alcian blue stain for chondrogenic differentiation.

\section{Cell seeding onto the scaffold}

In order to rule out any microorganism proliferation in the scaffolds, they were sterilized with UV light and cultured in expansion medium for 5 days. The scaffold was placed into a well of a 96-well plate for subsequent cell seeding, in a density of 1.0 $\times 104$ cells per well, in biological triplicates. During the period of 21 days, the cell-scaffold complexes were cultured with either expansion or differentiation medium in a 2D rocker system that completed 24 cycles per minute to aid homogenization of the cell-scaffold complex. In order to have a 2D environment, no scaffold control group, the cells were cultured in the absence of the scaffold expansion medium for 21 days. For primordial germ cell induction, the cells were cultured in a previously reported medium that was originally used to maintain ovarian cells in vitro, but also was able to successfully differentiate MSC into PGC-like [34,35], which was DMEM supplemented with $10 \%$ FBS, $0.1 \mathrm{mmol} / \mathrm{L} \beta$-mercaptoethanol (Sigma-Aldrich), $10 \mathrm{ng} / \mathrm{mL}$ LIF (Santa Cruz Biotechnology, Santa Cruz, CA, USA), $20 \mu \mathrm{g} / \mathrm{mL}$ transferrin (Sigma-Aldrich), $5 \mu \mathrm{g} / \mathrm{mL}$ insulin (Sigma-Aldrich), $60 \mu \mathrm{mol} / \mathrm{L}$ putrescine (Sigma-Aldrich), $10 \mathrm{ng} / \mathrm{mL}$ EGF (mouse epidermal growth factor; Invitrogen), $40 \mathrm{ng} / \mathrm{mL}$ human GDNF (glial cell line-derived neurotrophic factor; Invitrogen), $1 \mathrm{ng} /$ $\mathrm{mL}$ human bFGF (basic fibroblast growth factor; Invitrogen) and $2.5 \mathrm{mg} / \mathrm{mL}$ of amikacin.

\section{Scanning Electron Microscopy (SEM)}

In order to evaluate cell interaction with the scaffold, biological triplicates of the cell-scaffold complexes were observed using a scanning electron microscope (Zeiss EVO MA-10). After 21 days of culture, the complexes were fixed in Karnovsky solution for $48 \mathrm{~h}$ and dehydrated in ethanol. Prior to observation with the microscope, the complexes were dried with critical point equipment and metalized in gold.

\section{Histochemical staining}

In order to visualize levels of interaction between the cells and the scaffolds, a histochemical staining assay was performed on the biological triplicates of cell-scaffold complexes using Hematoxylineosin staining (HE). After 21 days of culture, the cell-scaffold complexes were fixed in $4 \%$ buffered paraformaldehyde (PFA) for $48 \mathrm{~h}$, dehydrated in ethanol, diaphonized in xylene, embedded in paraffin, sectioned by a microtome, and placed onto glass slides for visualization by light microscopy (Eclipse 80i, Nikon).

\section{Immunohistochemical staining}

Cells at the first passage, cultured in the absence of the scaffold, were fixed with $4 \%$ PFA for $48 \mathrm{~h}$. The cell-scaffold complex was also fixed with $4 \%$ PFA for $48 \mathrm{~h}$ after 21 days, whether in the group cultured with expansion medium or differentiation medium. The cells and the complexes were incubated at room temperature for $1 \mathrm{~h}$ with a blocking solution with $2 \%$ bovine serum albumin/PBS, followed by overnight incubation with the primary antibodies. After three washing steps, the cells and the complexes were incubated with secondary antibody for $1 \mathrm{~h}$ at room temperature, followed by a 10 minute incubation with 4',6-diamidino-2phenylindole (DAPI) for nuclear staining in blue. The negative control was performed by the incubation of the cells or cellscaffold complex with the secondary antibody only. The cells and cell-scaffold complexes were observed in a confocal microscope (FV1000, Olympus).

\section{Results}

\section{Scaffold production}

The placental scaffolds were successfully produced and validated [33]. It is possible to observe the absence of cells after the decellularization process in Figure $1 \mathrm{~A}$ with HE stain and, by SEM analysis, the fiber arrangement can be observed in detail (Figure 2A).

\section{Cellular characterization}

Cell selection based on rapid adherence selected cells with fibroblast-like morphology, which can be observed in Figure 3. The cells grew in a homogeneous monolayer for more than 14 passages. Additionally, the isolated cells displayed typical mesenchymal cell surface antigens, such as CD90, CD105 and CD73, while they did not display hematopoietic markers CD34 and CD45, which can be observed in Figure 3A. Moreover, the isolated cells were able to undergo differentiation into two mesenchymal lineages: chondrogenic (Figure 3B) and osteogenic (Figure 3C), in compliance with the MSC characteristic criteria suggested by the International Society of Cellular Therapy [36].

\section{Cell-scaffold interactions}

Next, the MSC were cultured with the placental scaffold for 21 days in a dynamic $2 \mathrm{D}$ rocker system. As can be observed in Figure 1B, the cells of the control group, which were cultured with expansion medium, adhered to the scaffold. Additionally, those cells established cell-cell communication, and the filopodia may be responsible for cell adherence to the scaffold and monolayer growth (Figure 2B). 
A

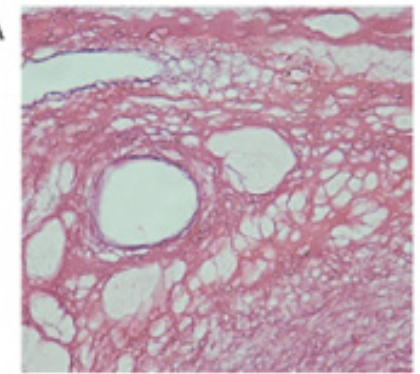

C

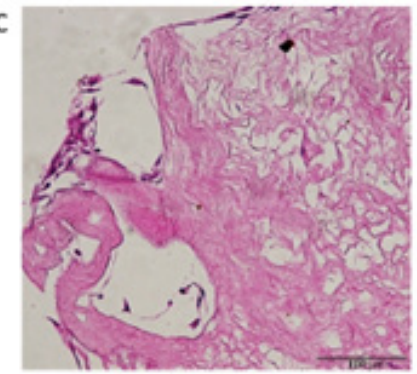

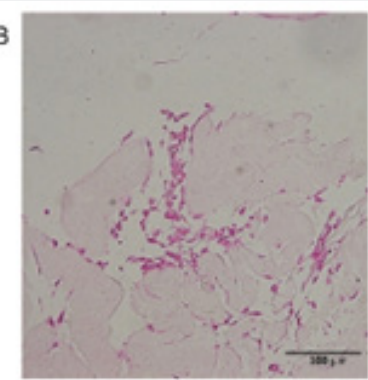

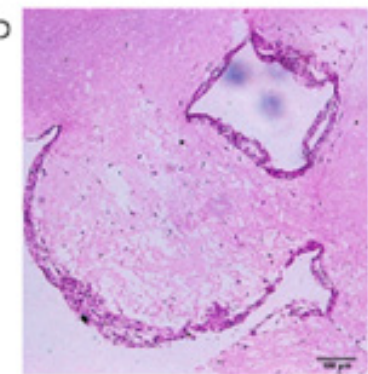

Figure 1: Scaffold histochemical HE staining. (A) The absence of cells on the decellularized placentae tissue. (B) Re-cellularization of the placental scaffold with mesenchymal stem cells after 21 days of culture. Primordial germ cell differentation on the scaffolds after a week of seeding and differentation (C) and after 21 days (D), evidencing cellular proliferation thoughtout the scaffold.
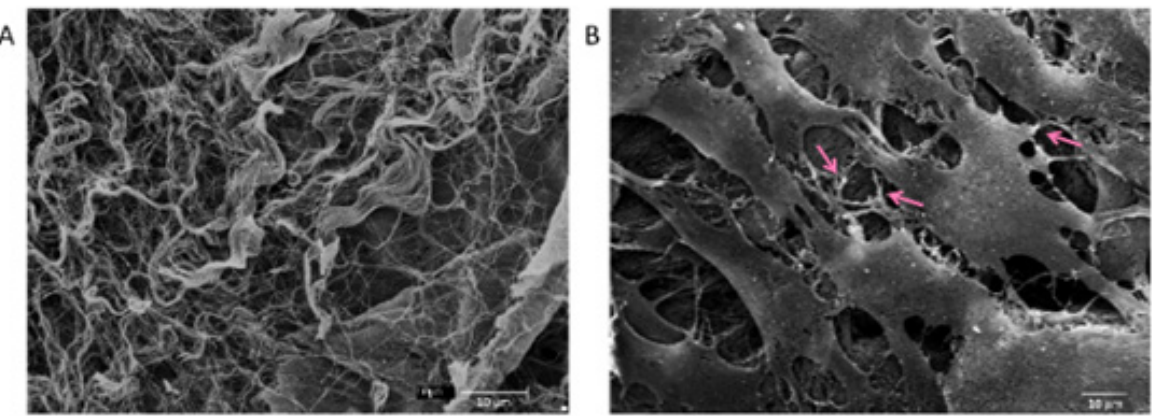

C
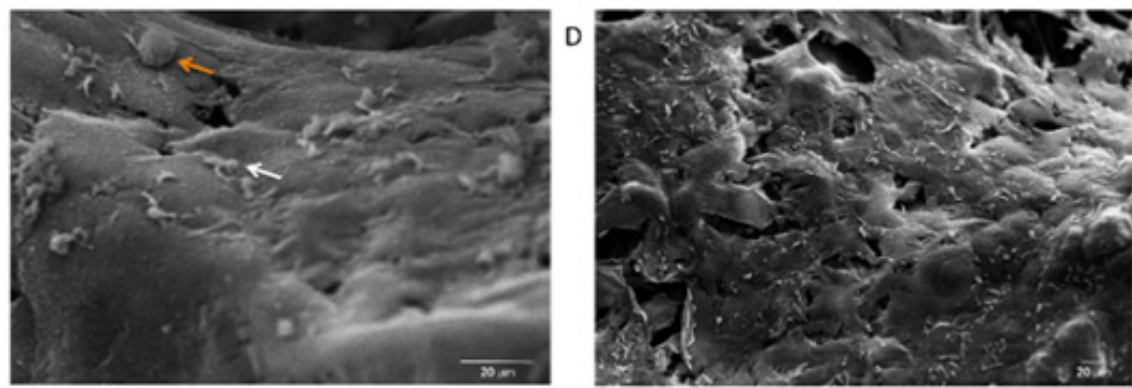

Figure 2: Scanning electron microscopy analysis. (A) The absence of cells after decellularization procedure of the placentae tissue, evidencing the maintenance and arrangement of fibers.(B) Cell growth and adherence after 21 days culture in the maintenance media, where cell projection, resembling filipodia can be evidenced by the pink arrows. (C and D) Primordial germ cell differentation, evidencing changes on the matrix, secretions and round cells, evidenced by the with and orange arrows, respectively.

\section{Cell differentiation on the scaffold}

Lastly, the potential of MSC to differentiate into PGC-like when seeded onto placental scaffolds was evaluated. In Figure 1C, HE staining reveals that the cells adhered to the scaffold one week after seeding, however, more cells are observed 21 days after differentiation (Figure 1D). After this period, the cells seeded onto the placental scaffolds displayed PGC related markers, including 
DAZL, VASA, STELLA and OCT4 (Figure 4). The SEM analysis shows cell morphology differentiation and cell secretion (Figure
2C \& 2D) when comparing the differentiated group with the control (Figure 2B).

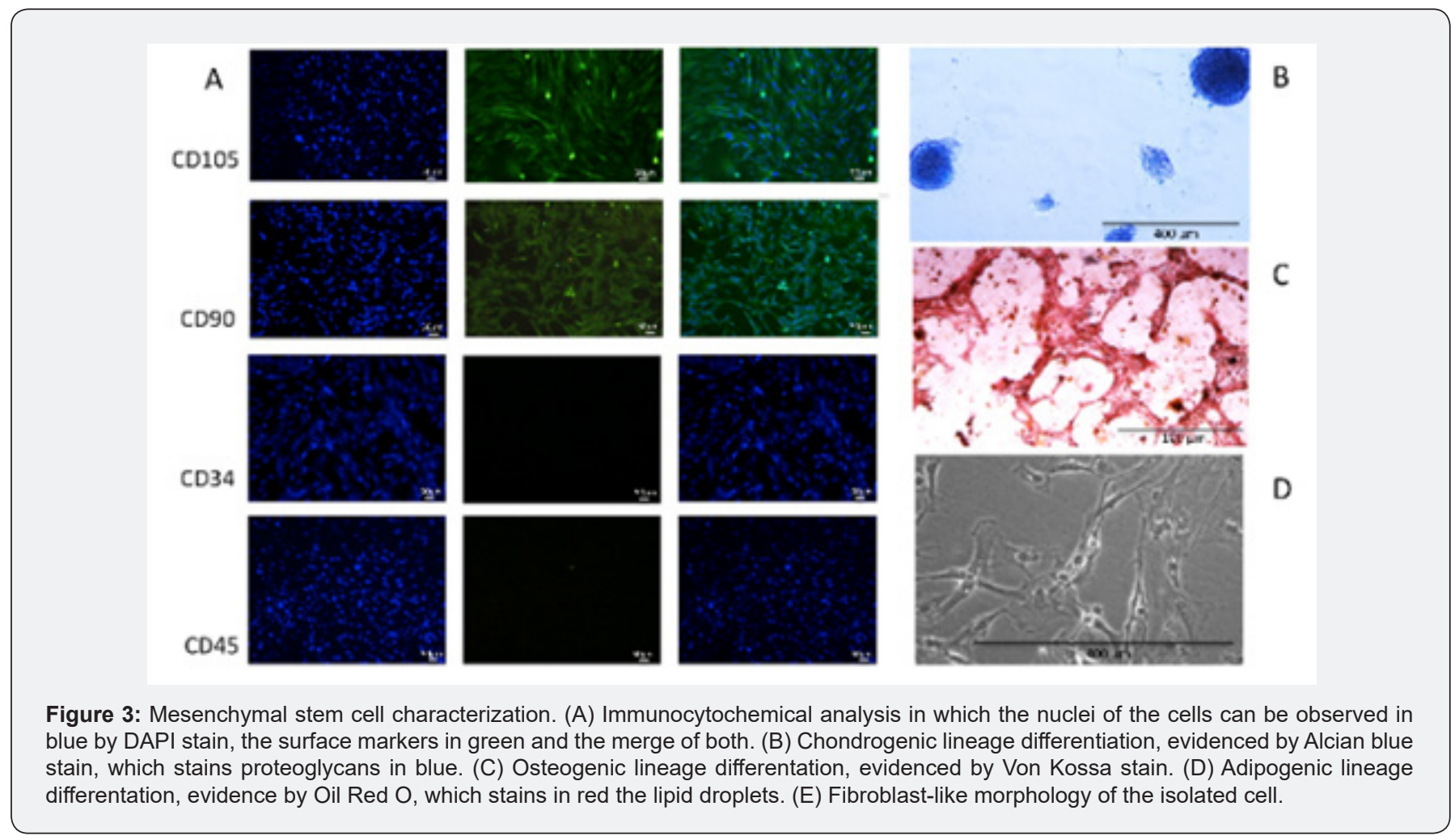

\section{Discussion}

The bovine species was chosen as the experimental model in this study due to its advantages over other translational models, such as rodent, which include more similar organ sizes and physiology than small animal models $[4,37]$. Concerning specifically the reproductive physiology, the bovine species is more closely related to humans in regard to folliculogenesis, oocyte development, endocrinal events and age related-events $[5,6]$. In the field of reproduction, mesenchymal stem cells have been reported to be a promising option for infertility treatment. This is owed to a number of beneficial qualities that they possess, including their wide differentiation potential [34,35] and paracrine effects, which modulate angiogenesis, cell proliferation, and apoptosis, as well as the fact that their isolation does not involve ethical concerns [31,32]. Previous studies have tested the effects of adipose derived stem cells on the regeneration of ovarian tissue, and it was observed that mesenchymal stem cells have the ability to prevent and rescue granulosa cells from apoptosis $[38,39]$, as well as increase the number of ovarian follicles [40-46] and the pregnancy rate [46].

The ability of mesenchymal stem cells to differentiate into germ-like cells under appropriate stimuli and to be transplanted into ovarian tissue has been previously reported [see review, 1]. However, it is known that 3D culture systems mimic in vivo conditions more closely than 2D systems, allowing for rates of cell growth, proliferation, and differentiation that are similar to those observed in vivo [47]. The ECM of placental scaffolds possesses a number of important similarities to that the in situ ovarian niche, for example, its richness in laminins and collagens [33,48-50]. Moreover, placental tissue is a very promising scaffold source due to its rich vasculature, abundant availability, and maintenance of fibers after decellularization [33]. Herein, we provide evidence that bovine mesenchymal stem cells can successfully differentiate into primordial germ cells when seeded onto placental scaffolds and cultured with specialized medium for natural ovarian primordial cells. This is the first report to show the differentiation of mesenchymal stem cells into PGC like cells in a 3D culture.

There are several important issues that should be taken into consideration when attempting a transplantation, including vascularization, oxygen levels, and graft size [11]. Regarding these issues, placental scaffold is an advantageous choice of material due to its well-developed vasculature and ability to build anastomoses with the host tissue [51,52]. Moreover, regarding vascularization and oxygen levels, mesenchymal stem cells are the best option to be transplanted with the placental scaffolds, since they have angiogenic abilities and stimulate the development of vessels in the transplanted area [53,54]. Another important topic is that of immune response to the transplanted graft, for which 
placental scaffolds seeded with MSC once again have a great advantage, specifically because of the low immunogenicity of MSC [54-56] and the fact that the decellularized tissue has low potential to cause inflammation and immune rejection once cell contents and antigens are removed [57]. However, an important concern of decellularized tissues is the remaining chemicals after the process that could possibly be harmful [57]. In this study, we provide evidence that the cells were able to grow, adhere, and proliferate when seeded onto the decellularized placenta, which demonstrated that, if there were remaining chemicals, they were not detrimental to the re-cellularization process. Now, specifically regarding ovarian graft transplantation, the primary concern is the functionality of the transplanted graft, since follicle activation leads to a decrease of the primordial follicle reserve, consequently decreasing the lifespan of the graft [11]. Placental scaffold with MSC could be an option to overcome the deleterious effects of this process, as MSC are known to increase blood vessel concentration, which, in turn, could stimulate the formation of new follicles and, incrementally over time, their activation, seeing as the ability of MSC to increase ovarian follicle numbers and improve folliculogenesis has previously been demonstrated [40-42].

PGC differentiation is a complex process. After embryo gastrulation, Oct-4 expression is confined to the germline, and is expressed again during folliculogenesis, coincidently with the entry into meiosis [58]. Due to the fact that Oct-4 is expressed by other cell types, including totipotent, pluripotent, and some somatic stem cells, it remains challenging to use it as a determining marker for germ cell specification [59]. Before colonizing the gonads, Stella may have an important role in germ cell development and differentiation [60]. The population of cells that express Stella seems to be a restricted lineage of germ cells, which continues the expression during migration to the gonadal ridge [61]. During the end migratory phase and arrival at the gonads, the PGC express VASA, which seems to be required for the maintenance of germ cell functionality $[59,62,63]$. After gonadal colonization, PGC are characterized by the expression of VASA, DAZL, and NANOS 3 [for review see 63]. Dazl is a cytoplasmic protein involved in primordial follicle formation [64]. In the present experiment, when the cell-scaffold complexes were cultured with ovarian cell expansion medium for 21 days, it was possible to verify the expression of specific PGC markers, including Oct4, Stella, Vasa, and Dazl, demonstrating the potential of those cells to differentiate into primordial germ cells after the transplantation of the MSC-scaffold complex into the ovary. In order to capitalize on the potential revealed by this experiment for advances in human reproductive medicine, further experiments must be conducted with the aim of specifying and clarifying certain important details. Chief among these is the in vivo evaluation of transplanted MSCscaffold complexes, which will provide data regarding the ability of the complexes to restore ovarian function. Another important matter to be investigated is whether a transplant conducted with MSC that have already differentiated into PGC-like would evoke a more efficient outcome than undifferentiated MSC with regard to restoring ovarian function. These proposed experiments would greatly further the potential of these techniques and clear the way for novel regenerative therapies to treat female infertility.

\section{Conclusion}

Here, we provide evidence of the ability of MSC to maintain their mesenchymal nature when seeded onto placental scaffolds as well as to differentiate into primordial germ cells when cultured in an ovarian cell maintenance medium. However, future experiments must to be performed in order to test the behaviour of the cell-scaffold complex in vivo.

\section{References}

1. Fazeli Z, Abedindo A, Omrani MD, Ghaderian SMH (2018) Mesenchymal stem cells (MSCs) therapy for recovery of fertility: a systematic review. Stem Cell Reviews and Reports 14(1): 1-12.

2. Rodriguez MH (2012) Assisted reproductive techniques for cattle breeding in developing countries: a critical appraisal of their value and limitations. Reproduction in domestic animals 47(s1): 21-26.

3. Abraham F (2017) An Overview on Functional Causes of Infertility in Cows. JFIV Reprod Med Genet 5: 203.

4. Hill ABT, Bressan FF, Murphy BD, Garcia JM (2019) Applications of mesenchymal stem cell technology in bovine species. Stem cell research \& therapy 10: 44 .

5. Sirard MA (2017) The ovarian follicle of cows as a model for human. Anim Models Hum Reprod 127: 44.

6. Malhi PS, Adams GP, Singh J (2005) Bovine model for the study of reproductive aging in women: follicular, luteal, and endocrine characteristics. Biol Reprod 73(1): 45-53.

7. Barbieri RL (2019) Female infertility. In: Yen and Jaffe's Reproductive Endocrinology. Content Repository pp. 556-581.

8. Lew R (2018) Natural history of ovarian function including assessment of ovarian reserve and premature ovarian failure. Best Practice \& Research Clinical Obstetrics \& Gynaecology 55: 2-13.

9. Peng G, Liu H, Fan Y (2017) Biomaterial scaffolds for reproductive tissue engineering. Annals of biomedical engineering 45(7): 15921607.

10. Kuo CY, Baker H, Fries MH, Yoo JJ, Kim PC, et al. (2017) Bioengineering strategies to treat female infertility. Tissue Engineering Part B: Reviews 23(3): 294-306.

11. Gavish Z, Spector I, Peer G, Schlatt S, Wistuba J, et al. (2018) Follicle activation is a significant and immediate cause of follicle loss after ovarian tissue transplantation. Journal of assisted reproduction and genetics 35(1): 61-69.

12. Krotz SP, Robins JC, Toni M, Moore R, Margaret MS, et al. (2010) In vitro maturation of oocytes via the pre- fabricated self-assembled artificial human ovary. J Assist Reprod Genet 27(12): 743-750.

13. Huet C, Pisselet C, Mandon P, Monget P, Monniaux, D (2001) Extracellular matrix regulates ovine granu- losa cell survival, proliferation and steroidogenesis: rela- tionships between cell shape and function. J Endocrinol 169(2): 347-360.

14. Kreeger PK, Woodruff TK, Shea LD (2003) Murine granulosa cell morphology and function are regulated by a synthetic Arg-Gly-Asp matrix. Mol Cell Endocrinol 205(1-2): 1-10. 
15. Kreeger PK, Deck JW, Woodruff TK, Shea LD (2006) The in vitro regulation of ovarian follicle development using alginate-extracellular matrix gels. Biomaterials 27(5): 714-723.

16. Smith RM, Ariella S, Kniazeva E, Deepa R, Teresa K, et al. (2014) Fibrinmediated delivery of an ovarian follicle pool in a mouse model of infertility. Tissue Eng Part A 20(21-22): 3021-3030.

17. Pangas SA, Saudye H, Shea LD, et al. (2003) Novel approach for the three-dimensional culture of granulosa cell-oocyte complexes. Tissue Eng 9(5): 1013-1021.

18. Xu M, Kreeger PK, Shea LD, Woodruff TK (2006) Tissue-engineered follicles produce live, fertile offspring. Tissue Eng 12(10): 2739-2746.

19. Arenas HJE, Ko IK, Atala A, Yoo JJ (2013) Decellularization for whole organ bioengineering. Biomedical materials 8(1): 014106.

20. Yu Y, Alkhawaji A, Ding Y, Mei J (2016) Decellularized scaffolds in regenerative medicine. Oncotarget, 7(36): 58671-58683.

21. Li YA, Li F, Zhang Z, Mingle Z, Cao S, et al. (2015) Bone marrow mesenchymal stem cells could acquire the phenotypes of epithelial cells and accelerate vaginal reconstruction combined with small intestinal submucosa. Cell Biol Int 39(11): 1225.

22. Ding, JX, Chen XJ, Zhang XY, Zhang Y, Hua KQ (2014) Acellular porcine small intestinal submucosa graft for cervicovaginal reconstruction in eight patients with mal- formation of the uterine cervix. Hum Reprod 29(4): 677-682.

23. Ho MH, Sanaz H, Dolores V, Istvan K, Monica G, et al. (2009) Stimulating vaginal repair in rats through skeletal muscle-derived stem cells seeded on small intes- tinal submucosal scaffolds. Obstet Gynecol 114(2 pt 1): 300-309.

24. Lemos N, Gil K, Ana L, Paulo A, Antonio P, et al. (2009) Small intestinal submucosa patch for extensive vaginal endometriosis resection. J Minim In- vasive Gynecol 16(6): 765-767.

25. Zhou QJ, Chen X, Luo X, Ding J, Zhang G, et al. (2013) Laparoscopicassisted uterovaginal anas- tomosis for uterine cervix atresia with vaginal aplasia using a silicone stent lined with acellular porcine small intestinal submucosa graft inserted using a 16F foley catheter. J Minim Invasive Gynecol 20(5): 710-713.

26. Farahat YA, Mohamed AE, Osama ME, Ahmad MT, Radwan MH, et al. (2012) Application of small intestinal sub- mucosa graft for repair of complicated vesicovaginal fis- tula: a pilot study. J Urol 188: 861-864.

27. BleggiTorres LF, Werner B, Piazza MJ (1997) Ultra- structural study of the neovagina following the utilization of human amniotic membrane for treatment of congenital ab- sence of the vagina. Braz J Med Biol Res 30(7): 861-864.

28. Alborzi S, Momtahan M, Parsanezhad ME, Yaz M (2005) Successful treatment of cervical aplasia using a peritoneal graft. Int J Gynecol Obstet 88(3): 299-302.

29. Laronda MM, Adam E, Kelly AW, Jason AW, Ramile NS, et al. (2015) Initiation of puberty in mice following decellularized ovary transplant Biomaterials 50: 20-29.

30. Zheng, Yue Liang (2016) Some ethical concerns about human induced pluripotent stem cells. Science and engineering ethics. 22(5): 1277 1284.

31. Kim HJ, Park JS (2017) Usage of human mesenchymal stem cells in cell-based therapy: advantages and disadvantages. Development \& reproduction 21(1): 1-10.

32. Samsonraj RM, Raghunath M, Nurcombe V, Hui JH, Wijnen AJ, et al. (2017) Concise review: multifaceted characterization of human mesenchymal stem cells for use in regenerative medicine. Stem cells translational medicine 6(12): 2173-2185.

33. Barreto RDSN, Romagnolli P, Mess AM, Miglino MA (2018) Decellularized bovine cotyledons may serve as biological scaffolds with preserved vascular arrangement. Journal of tissue engineering and regenerative medicine 12(4): e1880-e1888.

34. Hill AB, Hill JE, Bressan FF, Miglino MA, Garcia JM (2018) Derivation and differentiation of canine ovarian mesenchymal stem cells. JoVE (Journal of Visualized Experiments) 142: e58163.

35. Trindade Hill AB, Therrien J, Garcia JM, Smith LC (2017) Mesenchymallike stem cells in canine ovary show high differentiation potential. Cell proliferation 50(6): e12391.

36. Dominici M, Leblanc K, Mueller I, Slaper CI, Marini F, et al. (2006) Minimal criteria for defining multipotent mesenchymal stromal cells. The International Society for Cellular Therapy position statement. Cytotherapy 8(4): 315-317.

37. Roth JA, Tuggle CK (2015) Livestock models in translational medicine. ILAR journal 56(1): 1-6.

38. Fu X, He Y, Xie C, Liu W (2008) Bone marrow mesen- chymal stem cell transplantation improves ovarian function and structure in rats with chemotherapy-induced ovarian damage. Cytotherapy 10(4): 353-363.

39. Kilic S, Pinarli F, Ozogul C, Tasdemir N, Naz SG, et al. (2014) Protection from cyclophosphamide-induced ovarian damage with bone marrowderived mesenchymal stem cells during puberty. Gynecological Endocrinology 30(2): 135-140.

40. Fouad H, Sabry D, Elsetohy K, Fathy N (2016) Therapeu- tic efficacy of amniotic membrane stem cells and adipose tissue stem cells in rats with chemically induced ovarian failure. Journal of Advanced Research, 7(2): 233-241.

41. Abd Allah SH, Shalaby SM, Pasha HF, El Shal AS, Raafat, N, et al. (2013) Mechanistic action of mesenchymal stem cell injection in the treatment of chemically induced ovarian failure in rabbits. Cytotherapy 15(1): 64-75.

42. Mohamed SA, Shalaby SM, Abdelaziz M, Brakta S, Hill WD, et al (2017) Human mesenchymal stem cells partially reverse infertility in chemotherapy-induced ovarian failure. Reproductive Sciences 25(1): 51-63.

43. Song D, Zhong Y, Qian C, Zou Q, Ou J, et al. (2016) Human umbilical cord mesenchymal stem cells therapy in cyclophosphamide-induced premature ovarian failure rat model. Biomed Research International 2016: 2517514

44. Wang S, Yu L, Sun M, Mu S, Wang C, et al. (2013) The therapeutic potential of umbilical cord mesenchymal stem cells in mice premature ovarian failure. Biomed Research International 2013: 69049

45. Elfayomy A K, Almasry SM, El-Tarhouny SA, Eldo- Miaty MA (2016) Human umbilical cord blood-mesenchymal stem cells transplantation renovates the ovarian surface epithelium in a rat model of premature ovarian failure: possible direct and indirect effects. Tissue and Cell 48(4): 370-382.

46. Wang Z, Wang Y, Yang T, Li J, Yang X (2017) Study of the reparative effects of menstrual-derived stem cells on prema- ture ovarian failure in mice. Stem Cell Research \& Therapy 8(1): 11.

47. Evans ND, Gentleman E, Polak, JM (2006) Scaffolds for stem cells. Materials Today 9(12):26-33.

48. Berkholtz CB, Shea LD, Woodruff TK (2006) Extracellular matrix functions in follicle maturation. Semin Reprod Med 24(4): 262-269.

49. Heeren AM, Iperen L, Klootwijk DB, Bernardo A, Roost MS, et al. (2015) Development of the follicular basement membrane during human 
gametogenesis and early folli- culogenesis. BMC Dev Biol 15: 4.

50. Hummitsch K, Irving Rodgers HF, Hatzirodos N, Bonner W, Sabatier L, et al. (2013) A new model of development of the mammalian ovary and follicles. PLOS One 8(2): e55578.

51. Kakabadze A, Karalashvili L, Makashvili M, Abiatari I, Kakabadze Z (2014) Anatomical justification for the use of human placenta as a host for in vivo cell and tissue transplantation. Asian Journal of Pharmacy, Nursing and Medical Sciences 2(1): 31-34

52. Kakabadze A, Kakabadze Z (2015) Prospect of using decellularized human placenta and cow placentome for creation of new organs: Targeting the liver (part I: Anatomic study). Transplantation Proceedings 47(4): 1222-1227.

53. Huang NF, Li S (2008) Mesenchymal stem cells for vascular regeneration. Regen Med 3(6): 877-892.

54. Meirelles LS, Fontes AM, Covas DT, Caplan AI (2009) Mechanisms involved in the therapeutic properties of mesenchymal stem cells. Cytokine \& growth factor reviews 20(5-6): 419-427.

55. Frese L, Dijkman PE, Hoerstrup SP (2016) Adipose tissue-derived stem cells in regenerative medicine. Transfusion Medicine and Hemotherapy 43(4): 268-274.

56. Peroni JF, Borjesson DL (2011) Anti-inflammatory and immunomodulatory activities of stem cells. Veterinary Clinics of North America: Equine Practice 27(2): 351-362.

57. Gilbert TW, Sellaro TL, Badylak SF (2006) Decellularization of tissues and organs. Biomaterials 27(19): 3675-3683.
58. Pesce M, Wang X, Wolgemuth DJ, Schöler HR (1998) Differential expression of the Oct-4 transcription factor during mouse germ cell differentiation. Mechanisms of development 71(1-2): 89-98.

59. Toyooka Y, Tsunekawa N, Takahashi Y, Matsui Y, Satoh M et al. (2000) Expression and intracellular localization of mouse Vasa-homologue protein during germ cell development. Mechanisms of development 93(1-2): 139-149.

60. Saitou M, Barton SC, Surani MA (2002) A molecular programme for the specification of germ cell fate in mice," Nature 418(6895): 293-300.

61. Saitou M, Payer B, Lange UC, Erhardt S, Barton SC, et al. (2003) Specification of germ cell fate in mice," Philosophical Transactions of the Royal Society B: Biological Sciences 358(1436): 1363-1370.

62. Castrillon DH, Quade BJ, Wang TY, Quigley C, Crum CP (2020) The human VASA gene is specifically expressed in the germ cell lineage," Proceedings of the National Academy of Sciences of the United States of America 97(17): 9585-9590.

63. Nikolic A, Volarevic V, Armstrong L, Lako M, Stojkovic M (2016) Primordial germ cells: current knowledge and perspectives. Stem cells international 2016:1741072.

64. Ruggiu M, Speed R, Taggart M, McKay SJ, Kilanowski F, et al. (1997) The mouse Dazla gene encodes a cytoplasmic protein essential for gametogenesis. Nature 389(6646): 73

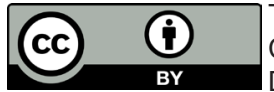

This work is licensed under Creative Commons Attribution 4.0 License DOI: 10.19080/CTBEB 2021.20.556028 